\title{
Visualisation of the "Denouements" in Cypriot Legends as Cultural Heritage: The Mountain/Well/Plain, and the Sea/Lake/Shore Themed Cypriot Legends
}

\author{
Gürkan Gökaşan ${ }^{1 *}$, Erdal Aygenç ${ }^{1}$ \\ ${ }^{1}$ Faculty of Fine Arts and Design, Near East University, Nicosia, N. CYPRUS
}

Received 19 September 2017 - Revised 29 September 2017 • Accepted 23 October 2017

\begin{abstract}
Legends as a part of intangible culture are known to provide information on their own culture as well as the perception structure of society. From our perspective, the legends, which can be taken into consideration from that dimension, would allow the interpretation of the personality of society in general through the expression and representation of their 'consequences'. The aim of this study is to understand the cultural structure over the written legends as a cultural heritage product in addition to illustrate the community perception in the most effective and efficient manner. Therefore, critical text analysis was conducted on the written legends and the representation style of every consequence in each legend was analysed. Additionally, in order to contribute the permanence the legends through illustration, the related scenes of the legends were re-structured with the digital collage technique. A mixed method comprised of "ready material use" by Cubism, "exaggerated style" by Dadaism, "manipulation" by Surrealism and "use of neon colours" of pop-Art in addition to the technique 'ripped paper texture' which is developed solely by one of three searchers were used in this study. 96 Cypriot legends given in the written records were analysed and only the "denouements" of the legends related with Mountain/Well/Plain and Sea/Lake/Shore covered. As a result, the common feature of the Cypriot Legends was found as "death" as referred by the "denouements". In other words, the final ending in the Cypriot Community is associated with death and additionally from the discourses of legends the society was identified as having a "patriarchal "socio-cultural structure.
\end{abstract}

Keywords: digital collage, Cypriot legends, visual text, culture, digital illustration

\section{INTRODUCTION}

Culture, which is comprised of independent pieces, can be defined as a well-ordered, functioning, well-structured system. Although each of these pieces is considered as a separate unit with their unique features and places within the system, their borders are generally uncertain. According to Aman (2012), regardless of a specific consistency among the parts of culture, there is no need to have a complete harmony through underlining the conflict between individual- group-entity as in every culture. In consideration of such remarks, the existing culture can sustain itself provided to absorb the conflicts and tensions (Aman, 2012).

The word culture is derived from the Latin word "Cultura" and French with the meaning to plant crop, discipline and raise (Aman, 2012). Culture that functions as a good-structured system, combines and comprises different pieces together. Culture has various definitions in the literature, yet it can be a common subject for social anthropology, history, sociology, ethnology etc. (Arslanoğlu, 2000).

As the culture can be categorised as tangible and intangible culture, it incorporates all kinds of elements performed and created by people. By defining tangible culture as all the materials created by the mankind, Arslanoğlu (2000) describes the intangible culture as "primarily the language, literature, art, science, philosophy, public beliefs and public culture, customs and traditions, ethics, norms, wedding styles, eating habits etc." (p. 8). 


\section{Contribution of this paper to the literature}

- The legends were taken into consideration as the personality of society

- The cultural structure is investigated over the written legends as a cultural heritage product

- The discourses of legends the society was identified as having a "patriarchal "socio-cultural structure

- The related scenes of the legends were re-structured with the digital collage technique

- It is noted that for the Cypriot community to perceive that there is no perception of an "end" in circumstances other than death

The intangible culture, which was particularly taken under the scope of this study covers arts, literature, intellectual activities and their products as indicated by Gümüştekin (b.t).

Through stating that the future of a community blossoms around the art, literature and intellectual acts, Gümüştekin (b.t.) aims to emphasize the significance of culture within the social structure. Additionally, he describes the artist, literati and intellectuals as the messengers of future.

This study discusses the transformation of legends, which can be categorised as one of the intangible culture products, in understanding the perception structure of related culture and society, interpreting the existing "denouements" conception and contributing the artistic transformation, structuring of legends as literary works in "denouements" through the digital collage technique in an applied manner.

The reason of using red and blue colours in the applied works is that blue was preferred in describing dominant male discourse and "effectiveness" in legends with blue and fury of God with red-the colour of blood.

The research formed the Cypriot Legends on the basis of certain techniques of Cubism Dada, Surrealism and Pop-Art and a new method was aimed to be created through "the ripped paper texture" technique developed by the researcher in addition to the "mixed" method; hence the scenes given under the subject were illustrated with the digital collage technique.

Within this framework, the main aim of this study can be summarized as learning about cultural structures through written legends, which are the cultural heritage, in addition to illustrate the social perception in the most effective and efficient way through the subject.

\section{THEORETICAL FRAMEWORK}

\section{Cultural Heritage and Significance of Culture for the Society}

'Cultural heritage' is defined as the discussion of connection between the values and characteristics handed over to children from their families and educational success (Bahar, 2009; Rojewski, J. W., 2005).

'Cultural heritage' is the source describing the mutual past of individuals with a community and strengthening their mutual bonds and feelings of unity. Cultural heritage enables people to take their experience and traditions from the historical development to the future and build their futures on an appropriate basis. The cultural heritage must be protected as it includes new disciplines, developments and memories to remember for the new generation in addition to values. Moreover the cultural heritage nurtures creativity and exploring instinct while bearing the traces of past disciplines with the contributions to life perspectives (Çekül, 2013).

Pursuant to Basat (2013), the studies regarding the protection, sharing and carrying to the future have "stable" and "dynamic" styles. Upon the assessment of such concept through cultural heritage, the tangible culture is found as "stable" and intangible culture as "dynamic". In terms of protecting both cultural heritages and explaining the differences, a structure under tangible heritage interpreted in a more holistic approach than a previous structure within the dynamic of life around. Cultural policies are required to protect the cultural heritage and embrace a structure with both qualities (Basat, 2013).

The coverage of tangible and intangible values in our identity related with our culture and history defines the cultural heritage (Ahmad, Y., 2006). The historical cities, patterns, cultural natural views, monuments, archaeological sites are a part of culture heritage as much as legends, traditions-customs, dance and language/accent. They all build bridges between the past and present through providing a foundation into the world and future.

In consideration of aforementioned statements, this study aims to structure the Cypriot legends, which have historical importance and a representative of Cypriot community and the narration styles in these legends in addition to discussion the representative problem and "denouements" within the framework of suggesting ideas to the future generations about the Cypriot identity to some extent. The transformation of legends as an example to intangible culture was structured through the illustration of written texts. 


\section{Legends as Cultural Heritage}

From the etymological point of view, the world is originated by the word "propriety". It has a meaning of "good habit, invitation, manners and morals" in the Ancient Arabic.

The definition of literature have various meaning in various different resources. According to the definitions where the literature is defined in frequent and settled manner, the literature is a field of art aiming the dynamic, effective and good description of the feelings and ideas among people and their communities. Every printed and published work is covered under the concept of literature. Therefore, the literature can be considered as a significant and inseparable part of culture and civilisations history. There are also limited definitions of literature. For instance, all writings and works under a certain science discipline are also under this scope; such as Law Literature, Astronomy Literature and medicine Literature. The literature also covered under the framework of all artistic work belongs to a nation, country, era or period. Folk literature, Divan Literature and French Literature can be also considered as examples to such (Özdemir, 1994).

The literature that is widely used in the various fields of Turkish intellectual and cultural life also covers the writings and works on the science or art. The literature is also known as having an impact on defining the formations of literary movements. Additionally, the word 'yazın' is also used for 'edebiyat' (literature) too. As literature is one of the elements of culture, there had been a need for the societies to assess the place of societies under the literature (Kaplan, R. K., İleri, C. \& Öztürk, A. 1998)

According to Bülbül, Türkoğlu and Küzeci (2014), the literature is at times for rebellion and questioning. Indicating that literature is a communication channel within the consciousness of people, Bülbül, Türkoğlu and Küzeci stated that it is also a lifestyle that might lead the people as well as societies (Bülbül, M., Türkoğlu, S. \& Küzeci, D., 2014)

Kösemihal (1967) describes that the people, characters and types in a literary work is related with the social environment of that literary work. As these people are related with a specific region (From Kayseri, Laz etc.), they might also be related with a society (soldier type, national heroes etc.). They might also be spread to a wider geographical region or a common hero of a cultural domain. For instance, Don Juan type is beyond its own national borders and has international recognition (Kösemihal, 1967).

Elbir (2006) defined the concept of public as a group with people that speak the same language, have common traditions and customs, laugh and cry to the same things and have close socio-cultural relations. Pursuant to Elbir, one of the characteristics of folk literature is being oral (Elbir, B., 2006)

Communities around the world have adapted to the conditions that they live in and developed their own unique life styles. Everything, which is the result of lifestyle that enables the people to develop within the certain constant conditions, generates the culture of existing society. The number of culture varieties increases with the number of communities in the world. Language, beliefs, values, rules, ceremonies, dressing styles and even war weapons bare the traces of culture. Additionally, legends, tales and epics are also considered as the part of culture (Roth, K., 1998). Tangible and intangible elements comprise the culture and become a part of that society. While the society and individual cannot be considered separately from each other but also becomes the society through absorbing the culture of that society. It has become a part of society with the cultural background acquired from the society that a person is born and raised. Culture, which is handed over from generations as getting broader, is a change and interaction that the existence of people remains indebted (Nesim \& Öznur, 2011)

Culture, which is mainly analysed under the ethnology, has been addressed as a common subject of ethnology, sociology, social anthropology, and folklore. As indicated by Nesim \& Öznur (2011), ethnology is a science regarding with the interpretation of having a unique cultural heritage among the people with relationships for many years from the perspective of society or community, and the assessment of their cultural heritage. Moreover, ethnology might be explained as a science that researches about, categorise, assess and interpret the culture with its own methods in the way to shed light to the future. Today, the researches and methods conducted on behalf of ethnology indicate the development and enriched content. Although the ethnology studies conducted in Cyprus are still new, there are particularly many works contributing to the tangible and intangible culture as "ethnology".

The relation between mythology and written literature, folklore and written culture is at various levels and such relation allows understanding the unique expression styles of aesthetic discourse and expression codes. According to Bayat (2016), mythology reflects the history of aesthetic discourse and also codes the visibility within the same period. Noting that the myths are mainly a model code for the written literature; Bayat argued that the existence of written literature changes the verbalisation in addition to changing the relation with the myths (Bayat, F. 2016).

Legend, as "söylence" in Turkish, is originated from the same Latin root "legendus" in the western languages. Legends that are one of the literary concepts are defined as "fictional story, myth about the extraordinary creatures, and events from the past" under TDK. Additionally, etymology Turkish dictionary (online) indicated the legends as originated from the Persian word afsāne أفسانه and cited from the word "story, epic". 
Unlike the western communities that use this word as legenda, legend, leggenda, leyanda etc. for legend, Arabs use ustûre, Greeks mythos and Germans sage. In Anatolia, the words of efsane, menkabe, esatir and mitoloji whereas Azerbaijani use esatir, mif, efsane for this concept. In the "Ottoman-Turkish Encyclopaedic Dictionary", Ferit Devellioğlu defined the legend as fictional story, meaningless word, story and absurd in his first definition and as story/events known by everyone and famous.

Just like other social products, legends might be considered as advising culture readers on the related societies.

Hence, the way of teaching, discussing or representing leads the readers together with the social structure dynamics.

The main reason to analyse the connection of legends converted from oral to written and to be illustrated under this study to the "denouements" is to understand the approach of societies on the "endings", which can be considered as the approach for conflict resolution. Therefore, such study might be a first step towards a comparative study for Eastern and Western cultures. This study is acknowledged to provide information about the Cypriot culture, which is possible to analyse within the Eastern culture and consequently the perception of society on "denouements".

\section{Relation of Culture and Art}

As indicated before, if culture covers every tangible and intangible product of a society or group, then art and art works can be analysed as a product of a cultural structure or process of a society.

In consideration with Akdoğan (2011), art, as one of the main components of culture, is defined as covering "the complete principles, method and information related with the realization of an activity or study" (p.213). According to the author, the human activity regarding with the transfer, expression and sharing of aims, thoughts, emotions, events and consequences through the skills and imagination are also covered under the artistic activity. Within this perspective, it might be assessed as a communication tool at the individual level at the core of artistic activity and a cultural product at the social level. Ünver (2016) noted that the style and meaning of art is directly related with the structure and geography of society; and highlighted the relationship between art and culture. According to the author, art is comprised of embodied and structured expressions of the cultures within the society and a language of the social structure.

While İslimyeli (1973) defined the concept of art as "the complete method and creativity in delivering an emotion, design and beauty"; Turkish Language Association explained art as "the complete methods used in the expression of an emotion, design or beauty, or the superior creativity resulting from this expression (TDK, 1992). The creativity, beauty and sharing are the common components literature and the both definitions.

Bingöl (2010) categorises art as the fine arts and free arts. According to Bingöl, the fine arts are mainly oriented to the aesthetic results while free arts cover language, speech and expression via logic. Bingöl also indicated that apart from the fine arts and free arts, architecture, pottery, weaving and graphic design might also be considered as art.

Moreover, Bingöl classified literature, visual arts, graphic arts, plastic arts, decorative arts, performance arts, music and architecture as art related domains.

Hence, each product that is covered under the literature is also defined as a part of related culture and correlated with art.

Even if the changing social relations changed and still change the art works as Çeçen (1984) noted, then the evolution of art shall not be taken into consideration separate from the evolution of art.

In this context, the philosophical approach "art for people's sake", which is one of the two main opinions on the function of art, should be embraced. According to this understanding, art is discussed as a product of a socialrealistic opinion and hence is considered as one of the means in the reflection of reality by the social consciousness rather than expressing the beautiful (Bingöl, 2010). In other words, under the perception of "art for people's sake", "description of reality" is taken as a basis for the basic function of art rather than "description of beauty". The view of Binyazar (2010) that art ensures the exhibition of social problems is understood as the emphasis for considering the art to be a mirror of society. According to him, a person can reveal the long-established relation between the world and existence through art, while art enters into re-creation period raising from the design of changing via art.

Education directly or indirectly affects the sociological, cultural and economic development of societies. It is beneficial to say that education is available both at the school but outside the school as well. According to Türkkahraman (2012) education covers all individual acquisitions. Hence, the author discusses the significance of education in terms of socio-economic level and emphasises that the economic value of education is based on the attitudes, values, social and communicational skills rather than generative values and technical information. 
No doubt that there are a number of studies regarding the importance of art education among children. The study conducted by Ülker (2012) noted that the students drawing nature can effectively perform the positioning of size, shape and nature. Therefore, the children are able to perceive and draw the elements of nature more clearly while growing older.

As stated by Yilmaz \& Kahraman (2015), Artut (2012) underlined the important role of art in the mental development of children. While noting that art is a psychological action, Yilmaz \& Kahraman indicated that the elements like colour, form, word, line and rhythm are blended with the individual perspectives

Furthermore, the aim of this study can be summarised as the illustration of "denouements" identified within this framework and strengthening the permanence of legends.

\section{Summary of Cubism, Dada, Surrealism and Pop-Art Relationship}

Pursuant to Oskay (2003), Cubism was emerged as an art movement in the early $20^{\text {th }}$ century questioning art as a new way of expression through the impact of invention of photography, improvement of nature sciences and examples from primate art. The mobility of artists from various art movements from one group to another contributed to the art movements. The starting point of such movements is no doubt the idea of 'appeal to the imitation of real' and 'liberalisation of styles in the works'. According to the author, Cubism, which was the only movement introducing a new style to the expression, was not stayed silence against the development of science and technique and introduced a new art movement in the partnership of George Braque and Pablo Picasso eliminating a single point of view.

McNeese (2006) indicated that Cubism had been a milestone for the beginning of Pablo Picasso's career in 1906. Picasso, who conducted various works until 1907, had sought new materials after that and started using such materials in his works. He had drawn human figures as deformed, used lines with various angles, turned the human head by 180 degrees and arms and legs in impossible angles. Within this perspective, the rule of 'golden ratio' had become extinct by the leading cubism artists as Picasso, Braque and Gris, and then Picasso introduced the collage art with his work called in 1912 'Still Life with Chair Caning' (McNeese, T., \& Picasso, P., 2006)

Cubism, which is based on separating the objects into pieces and then shaping them by a new expression style through re-interpretation; is analysed in two different periods as "analytical" and "synthetic" (Oskay, 2003). Houser (1958) described "the attitude against reality" raised with incapacitating the impressionism as the biggest reactive act of the century (Houser, 1958).

Created by the young artists in 1915 as a myth, Dada was originated in Zurich, which is described as a passive city overlooking the destruction of World War I. while the war continued on one hand, the artists performed their art in a cynical style and showed their reaction to the war with 'refractory'. The movement of Dada was created with another way of expression that would lead art to another level, and always had the determination to re-create each domain under the art. Kentsoylu emphasized the absurdity of beauty under the art of Dada where a new style of creativity replaced the style of unacceptable pristine culture. A free style that the painters interpret the material as it is rather than describing and think from a different perspective than the specific colours, styles of art was introduced to art (Dachy, 2006).

Pursuant to Hoffman (1996); the origins of Dada had arose in Zurich by February, 1916 and founded at a tavern known as Cabaret Voltaire. The movement introduced under the leadership of German poet Hugo Ball had been developed together with other writers and artists asylum in Zurich due to World War I. The environment created by Ball had become suitable for artistic freedoms and experiences, and triggered the rise of rebellion. The first cover of magazine 'Der Dada', which was published to communicate with Berliner Dadaists and spread the movement much wider groups, was designed by Raoul Hausmann with collage technique in April 1920. Hence, Dada reflected the attitude on art via collage technique (Hofmann, I. E. (1996).

Known as the founder of Surrealism, Andre Breton was interested in the studied on the sub-consciousness due to his education of Medicine and Psychiatry, and he followed the studies of Sigmund Freud. On the other hand, the term of Surrealism first used in a programme noted of a ballet performance organised by Guillaume Apollinaire and Erik Satie and Jean Cocteau in 1917 called "Parade" and in the play named "Tiresias' 1 n Memeleri (Breasts of Tiresias) organised the same year. (Vangölü, 2016). As reflected by Vangölü, Breton (1997) defined the movement of Surrealism as a pure mental automatism aiming to reflect the real activities of thoughts via words or writing. According to the author, Surrealism is defined as the existence of thought far from the mind imposed control mechanism and aesthetic or ethical supervision. In another definition, it was explained as a belief based on the reality of avoided association, absolute influence of dreams and objective games of thoughts.

In consideration with Sözen and Tanyeli (1992), Pop-Art, which is an art movement started in England at the end of 1950s and spread to Europe and America in 1960s, had mainly focused on picture and graphic arts. Pop-Art discusses the explaining the industrialisation and daily consumption culture with the methods from the mass communication era. The insulation of such subjects was represented in exaggerated sizes through comic or 
advertisement (Sözen, and Tanyeli, 1992). According to Smith (1996), the launch of Popo Art was based on the studies and researches of Surrealism covering sub-consciousness, acts of Dada towards changing the border of art and the initiatives to encouragement of Dada in addition to working towards changing the borders of traditional art and experimentality incorporated to art by the abstract expressionism (Edvard 2004).

In this regard, the related art movements overlap under "collage" from the technical dimension and "resistance" ideologically. Therefore; "the digital collage technique" was used in the illustration phase of this study and the "resistance" in the oral/written styles of "denouements" is especially highlighted in the visuals.

\section{A Short History of Cyprus Island}

The history of Cyprus island that had been the centre of various civilisation goes back to the New Stone Age B.C 7000- 3000. Following the Bronze Age B.C. 3000-1450, Cyprus was administrated by the Hittite Civilisation between B.C. 1500 - 1450 and then Ancient Egypt Sovereignty. After the Assyrians between B.C. 700 - 545, Iranian Persians between B.C. 545 - 345 and Ancient Greeks (Helen) Administration was in B.C. 345 - 290. Being under the sovereignty of Ptolemaic Kingdom between B.C. 290- 58, the Cyprus was then under the administration of Romans for B.C. 58 - A.C. 395 and then Byzantines between A.C. 395 - 1190 and the First British administration between 1190 - 1191. The British Sovereignity continued just for one year and then Lusignans between 1191 and 1489 and Venetian Administration between the years of 1489 - 1570. The governance of Ottoman Empire was between 1570 and 1879 and then the island again got under the administration of British. The island stayed under the British administration until 1960. The first Republic in the island was established in 1960 and the Republic continued for 14 years. Divided in 1974, the Turkish Federated State of Cyprus proclaimed and then the Turkish Republic of Northern Cyprus in 1983, which still governs the northern part of Cyprus (Nesim and Öznur, 2011).

\section{METHOD}

During the illustration of scenes from the legends that were illustrated with the digital collage technique, only the movements of Cubism, Dada, Surrealism and Pop-Art were taken into consideration for the influence.

From this perspective, "the use of ready material" of Cubism, "exaggeration" of Dadaism, "manipulation" of Surrealism, "neon colour" of Pop-Art were taken as a basis for the illustration of legends.

Additionally, the "ripped paper technique" developed by the researcher was included to develop a new style.

Adobe Photoshop program was used in the illustration of written legends for the digital collage.

Moreover, critical text analysis method was used to identify and analyse the related scenes of legends and the semantic structures of words that were possible to affect the discourse structure was also assessed. Hence, such approach helped to determine whether there are any possible subliminal messages, which are sub-meanings and if any, the content of such messages; and the discourses that have the ability to structure our world was also analysed.

\section{CASE STUDY}

As a basis in the study, 'Turkish Cypriot Ethnology Oral Culture Assets: Our Legends' by Gökçeoğlu (2004) was taken basis in the study and the legends taken under the scope of this study were identified as having no other variations. The compilation called Cypriot Turkish Folklore Oral Culture Values: Our Legends by Gökçeoğlu as the main reference within the Cyprus Literature textbook is covered in the Secondary Education curricula of the Turkish Republic of Northern Cyprus was taken as a basis being recorded the highest number of legends.

In consideration with the studies, which reflected that the Greek Cypriot Legends and Turkish Cypriot Legends are not separated clearly in the literature, hence this study considered not to separate the legends within the scope of this study as Greek Cypriot Legends and/or Turkish Cypriot legends. Therefore, the study used the definition of "Cypriot legends". Additionally, various legends such as the Aphrodite are both a part of Turkish Cypriot Literature and Greek Cypriot Literature.

There are a total of 96 Cypriot legends classified under 24 categories under the related publication. 6 legends categorised as Mountain/Well/Plain and Sea/Lake/Shore among 96 legends classified in terms of their similarities were considered as data in this study.

96 legends in total were then reduced in a rational way and the first thing taken, as a basis was the reclassification of the categories. Therefore, the legend classifications were put a heading that include "transformation" in various ways and the legends with the relation of elements of mother nature (mountain, sea, plain, spring etc.) and the legends that cover living beings rather than human are put under another heading. 
The legends that were related with the mothernature generated after the reclassification were given as the legends on Mountain/Well/Plain and legends on Sea/Lake/Shore; the ones that include "denouements" were taken as a basis.

These legends as "Beşparmak Dağ1- Beşparmak Mountain”, "Aslan Ali- Lion Ali”, "İhanetin Bedeli - Price of Betrayal" and "Gavur Kayaların Gözyaş1- Tears of Giaour Rocks" for the legends on Mountain, Well and Plain; "Püsküllü", "Tuz Gölüne Dair Efsane- legend about the Salt Lake", "Yılan Adası- Snake Island" and "Sarnıç Kızlarının Ölümü- Death of Cistern Girls" were taken from the literature.

\section{LIMITATIONS}

Within the scope of Cypriot Culture and Literature, only Cypriot Legends were taken as a basis in this study. Moreover, the legends were also confined to a scene from 6 legends including "denouements" under the legends about the Mountain/Well/Plain, and legends about the Sea/Lake/Shore, which were visualised by digital collage technique.

The fact that Greek Cypriots and Turkish Cypriots had influenced from each other in terms of culture due to living together shall not be avoided. Thus, the ownership of legends given in this study as a cultural product is within a scope of another study.

\section{APPLICATION AND ANALYSIS}

\section{LEGENDS ABOUT MOUNTAIN, WELL AND PLAIN: The Related Scene Application and Semiotic Analysis}

\section{"Beşparmak Dağı/Beşparmak Mountain"}

Beşparmak Mountain legend is about duel of two young men for the women they love. The behaviour of man, who archly draws in his rival into the marsh that he was in, cost both lives (Gökçeoğlu, 2004).

Both men were sank into the marsh that they fell into and tried to survive and caused the death of both due to the canniness of 'mean-spirited' man. Pursuant to the legend, the visual of hand in the air representing the form of Beşparmak Mountains in its existing form is at the core of work. It is possible to interpret from the position of hand that the 'good-hearted' man drawn into the marsh was asking for help. The colour of hand that showed the last stand was chosen as brown, which is considered as the colour tone of marsh. The white torn forms in the palm symbolises him being unanswered for his call of help.

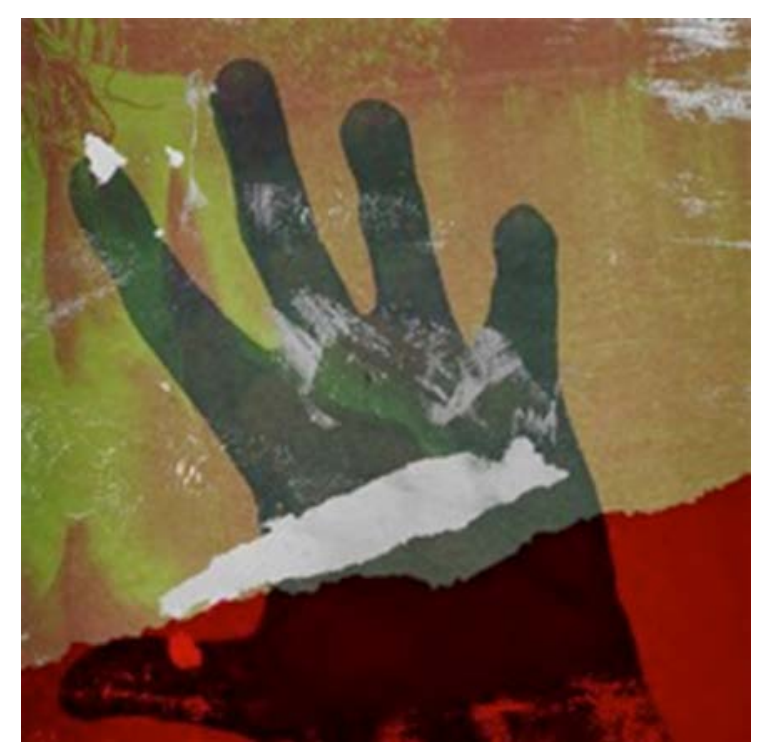

Figure 1. "Denouements" in the Legend of "Beşparmak Dağı" 
The woman figure at the back of hand facing back indicated that no one won this duel and the woman as the reason for this war stayed out of this war and went away. The ripped red paper texture at the bottom part of hand symbolises the death of both men at the end of this duel. The "denouement" of this legend was given as the formation of current Beşparmak Mountain.

\section{"Aslan Ali/Lion Ali"}

The main theme of the legend in a forest surrounding the Besparmak Mountains is the potential of humans to betray even the closest people, primarily the nature, in the interests of their own benefits. The son of the man, who was killed by the king in order to save the forest, is betrayed for the sake of 'love' by relying on the struggle and prince to protect the same forest (Gökçeoğlu, 2004). The story is about the the sadness and disappointment Aslan Ali went through the "denouements" of the story, he begged to the Prince to stop the cutting down of the trees and he devastation, he jumped of the abyss of the cliff of the forest that he loved so much.

Aslan Ali had been living the same disappointment of losing both his close friend and his favourite forest. Aslan Ali, could not accepted the fact that Prince gave the forest to the King despite his opposition as him being the close friend of the prince and regardless of how much he begged he could not manage to stop the Prince. Aslan Ali, who was destroyed in the face of this situation, came to the side of the cliff by not being able to stand this pain any more, left himself among the trees he loved very much and committed suicide. The male figure with his arms open and facing upwards refers to the desperation of Aslan Ali.

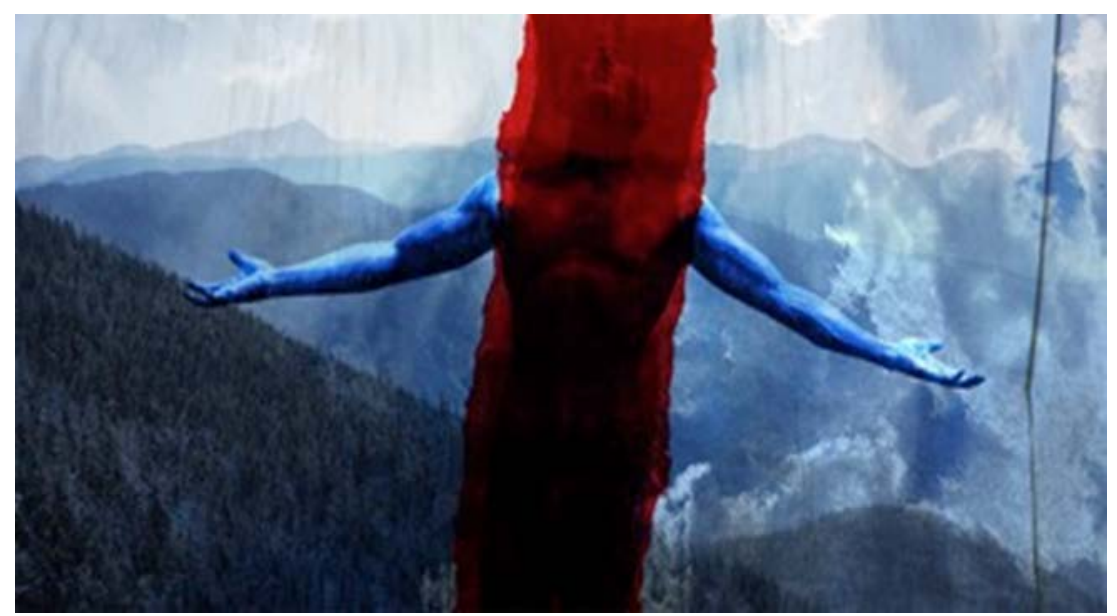

Figure 2. "denouements" in the legend of "Aslan Ali"

It can also be said that the figure with his hands and head upwards begged God in the face of helplessness. The male figure expresses the pain of suffering and the suicide path to bring its own end, which vertically covers the body, and the red colour symbolizes the death / blood at the end of this event. It is visualized in the red ripped texture that Aslan Ali, depicted in an indeterminate colour close black, died as the result of suicide. The foggy half of the forest covered with clouds represents the loss of the forest that was slaughtered.

\section{"İhanetin Bedeli/Price of Betrayal"}

This legend describes the lives of two fishermen who earn their living by fishing and the secret affair of the fisherman from Dipkarpaz who falls in love with the wife of the fisherman from Sipahi (Gökçeoğlu, 2004).

At the end of the legend; in the wake of the wrath of God, the "secret affair" ends with a lightning striking, where the couple were found, and since that day no living creature lived where there the lovers were found.

The fish visuals depicted on the bottom of the work represents the men as her husband and lover in the life of woman, who were fishermen. Birds pictured beside the fish and in a smaller form represent a supreme expression of the fact that the lives of both fishermen are subordinate to this event. The blue colour that makes up the sky represents both the sea where these two men have gained their lives and the sky they are living under. 


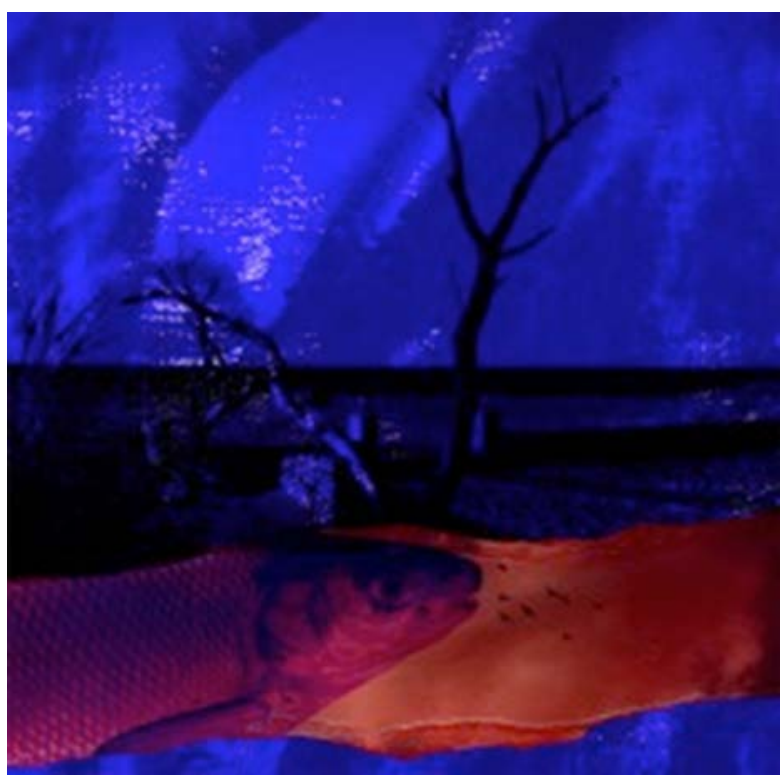

Figure 3. "denouements" in the "Ihanetin Bedeli" Legend

The expression that no creature has ever lived in where the "denouements" of the event has ended is represented by dry, black tree image in the middle of the visual. In addition, fish and birds in orange ripped paper texture symbolize the end of the living things in the region, in the secondary sense. The use of the fish in red tones explains the shame / embarrassment experienced by living beings.

\section{"Gavur Kayalarının Gözyaşı/Tears of Giaour Rocks"}

The legend of the Gavur rocks tells the events that can be counted as a kind of matchmaking under the leadership of the Abbot at the Bellapais Temple to the east of Kyrenia, causing the wrath of God and the disappearance of the Gavur rocks of all who are there. (Gökçeoğlu, 2004).

Gavur Kayalarl, where the virgin festivals are organized and where the Head Priest exploits religion, is painted with dark blue on the right side of the work. The physical proximity of the woman and man to each other, depicted in red, symbolizes the moment in which the feasts take place.

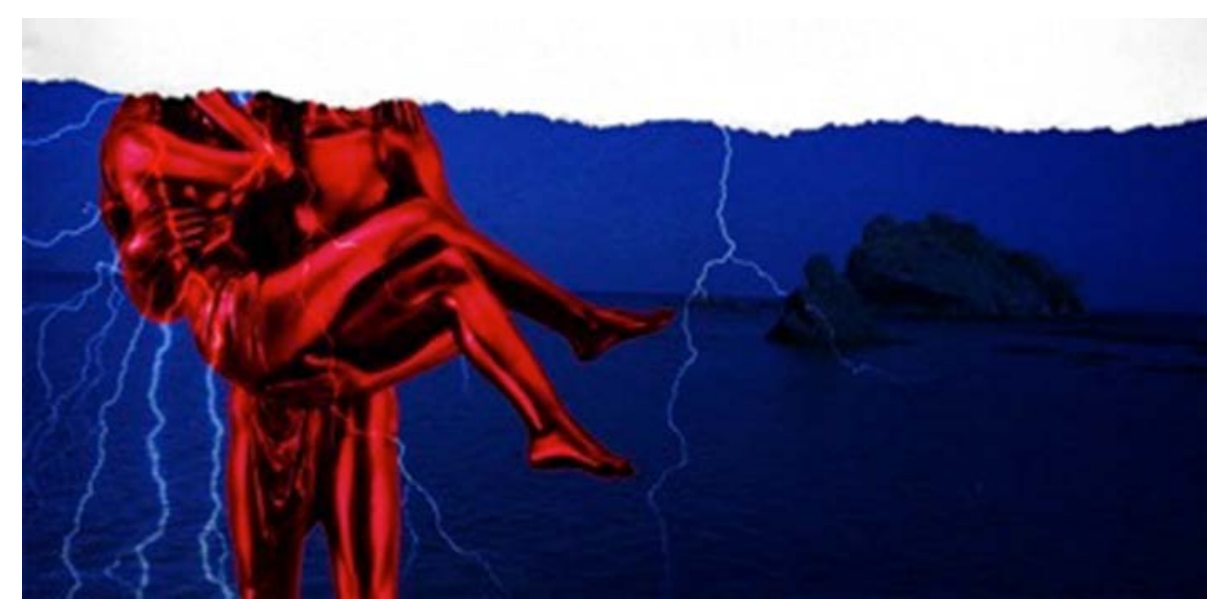

Figure 4. The "denouments" in the legend of "Gavur Kayalarının Gözyaşı."

The "denouements" of the legend are depicted in the dark blue colour of the cloaked and dreary atmosphere, while the "denouements" of the people do not end well, while trying to describe the suffering of God's wrath with lightning. Here, the researcher who depicts the image of the man holding a woman in her arms in the background of the flame red is again referring to the essence of lust and passion-based story. While trying to describe the white rip, lost moral values that make up the upper part of the visual, including the head of the woman and the man, it 
also points out the importance of what they are doing rather than who they are. On the dark blue ground, the Abbot's hegemony is represented on the girls who participated in the feast.

\section{SEA, LAKE AND SHORE RELEVANT LEGENDS: Relevant Scene Applications and Semiotic Analysis}

\section{“Püsküllü̈"}

The legend is about the feast which gather the "beautiful" and "ugly" people living in Kyrenia and starting fire on the sea on certain days to make this call, the "Püsküllü" who is famous for his strength and crazy characteristic caused him to lose the "spica-colored girl" that he fell in love with, even though he was killing her from his love.

Püsküllü who threw his favourite spica coloured girl to the sea was taken out from the cave where he secluded himself in and was taken back to beach by the other girls and forced to start a fire. With the sad song of the spica coloured girl coming from the sea, the Püsküllü let himself to the sea and disappeared in the dust cloud created by the huge waves (Gökçeoğlu, 2004).

People who were trying to bring together the Püsküllü and the spica coloured girl brought Püsküllü to the coast to start the fire. After the fire, Püsküllü could not stand any longer and let himself to the sea and committed suicide with the sad song sang by the spica coloured girl with the hope of coming together with her. The Püsküllü depicted by the blue, muscular male body at the bottom left of the work in red torn tissue. The red colour used in the death colour tells that this love was worth of the lives of both people. The spica field in an upside-down position representing the life of the spica coloured girl on the visual of Püsküllü who jumps to sea with a cloud of dust the cloud represent the "other world" in which they meet.

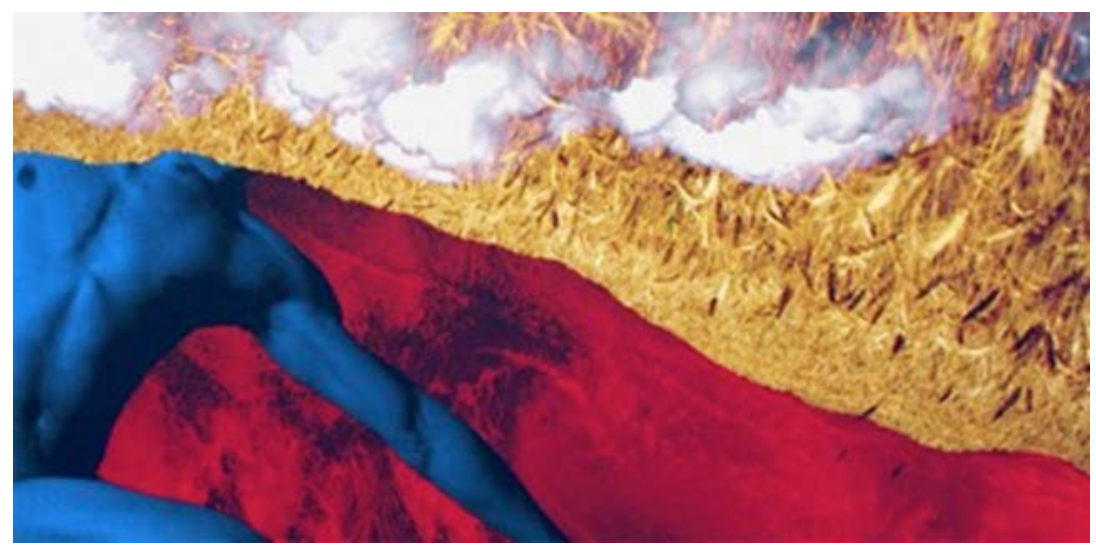

Figure 5. The denouements in the "Püsküllü Legend"

The red colour, which represents love / love in its secondary sense, expresses the love of the man who chooses to die for the love of the girl he loves. The life of the legendary man and woman is represented by the images used in reverse. The spica field representing the spica girl was used in reverse for the girl who is uncertain about, where and how she is. The clouds at the top of the work express the dust cloud, which the Pusküllü was lost, by jumping in to the water because he heard the voice of the girl he loved.

\section{"Tuz Gölüne Dair Efsane / Legend about the Salt Lake"}

In legend, the dervish was thirsty and asked for water from the vineyard which belongs to the old lady who lives in Iskele. However, the old lady refused to give him grapes and the man cursed the vineyard. The curse comes to true and the vineyard turns into a salt lake and the old lady turns into a rock. The dervish who was tired from thirst on the road died and the forked hand in his hand turned into a carob tree afterwards. (Gökçeoğlu, 2004).

God's wrath to the old woman, who turned the thirst and need of the dervish who is regarded as a sacred person in religious terms, with lie made her lost everything in her hand. The old woman who turned into a rock after the vineyard was destroyed paid the results of lying and stinginess in this way. The 'old' woman described in the legend of Tuz Gölü is depicted with a mud brick walled window structure, which is one of the characteristic features of ancient Cypriot houses. 


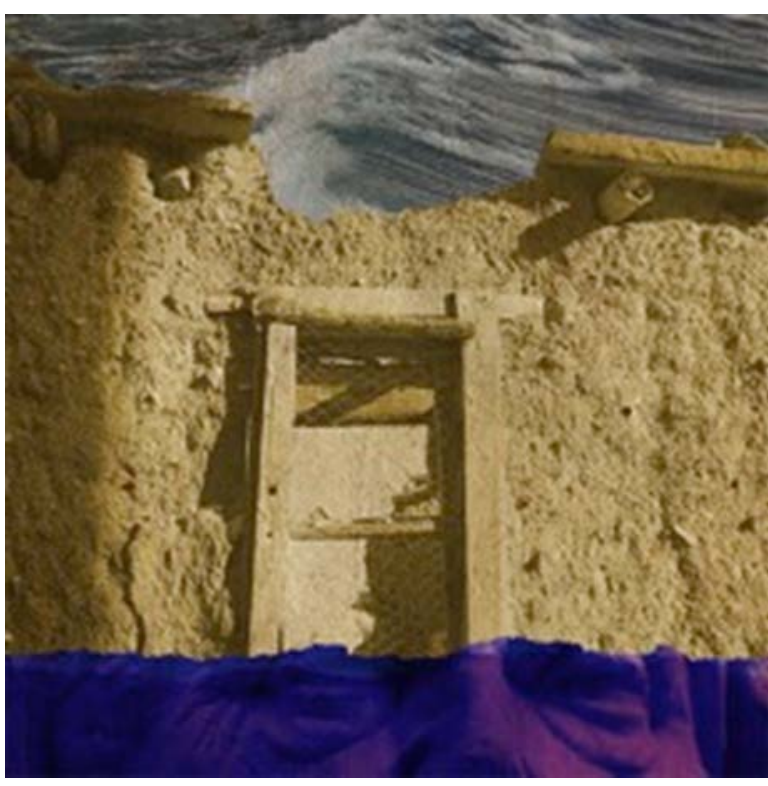

Figure 6. The "denouements" of the "Tuz Gölü" legend

The end of life which is the "denouements" of all of the legends, is depicted by the transparent blue torn paper texture of the old woman, the background on the bottom of the created image. The end of life is visualized with the wall of an old house with dysfunctional windows. Here is to emphasize the discretion of the ownership, which the researcher will not serve the purpose. At the top of the image where the sky is to be found in accordance with normal standards, the positioning of the sea is referring to the world and the human being as the opposite of the values.

\section{"Yilan Adası / Snake Island"}

The Legend regarding the Yılan Adası (Snake Island), known as Yasak Aşklar and Küskünler before, starts when a fisherman who lives in a place where living conditions are very hard with his wife and daughter drawn in the sea when they were trying to escape from the King. The King understands how hard it is to survive in that place and with admiring the loyal wife of the fisherman who was able to survive from the sea, he made a statue of the woman. The story ends with the King drowning while watching the sea with hope and with him dying. The King is removed from the stomach of a snake which is one the reasons why the legend is named "Yilan Adasi" (Snake Island). (Gökçeoğlu, 2004).

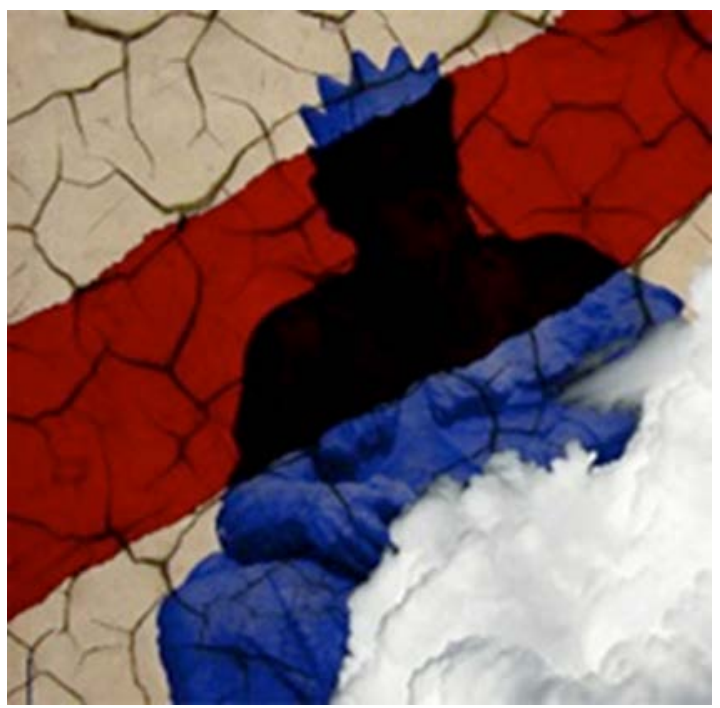

Figure 7. The "denouments" of the "Yılan Adası" 
The King who was overwhelmed with ambition and whose authority was shaken returns back to the island to find the family and he has caught an incurable disease. In the "denouements" of the legend the King overwhelmed with ambition is expressed in rushed and a dried form like mud. While the expression of the male hegemony of the King is supported by the blue colour, it is expressed by the mud texture that the island is buried in the water when it reaches the Yllan Adasi. The island is covered with a cloud of dust before it is buried in water and this is symbolized by the white clouds pictured under the king's figure.

The muddy body of the king points out that it has been removed from the sea. The horizontal red-torn tissue from the part of the king's face and heart represents death. The use of the black part of the red tissue that appears between the head and the chest as black represents the King identified as the 'bad' person. In addition, the mud texture on the grounds symbolizes the conversion of the island buried in the water turning back to land.

\section{“Sarnıç Kızlarının Ölümü/Death of Cistern Girls"}

In the Belen Cistern, which is located near the Castle of Hundred Homes in Kyrenia, where the shepherd named Vukua sacrificed his wife for the sins he committed and the legend is about the people being devoted as a vow and what really happens after a murder is committed. In the legend, the drought that is believed to be the curse of the murders and the famine that people are living in, is telling about making money by selling the virginity of the girls. The drought, which ended with the tears of a blind couple, ends with the suicide of this couple again (Gökçeoğlu, 2004).

The two lovers described droughts and troubles ending with their tears joined the feast in the cistern and disappeared among the sea foams, by jumping off from the cliff. It is possible to grasp the beloved by the hands and feet of the male and female visuals in the work of visualizing two lovers' leaving themselves to the sea. Coupled with the eternal journey after the jump to the sea, the couple is represented by the image of birds flying over the sea.

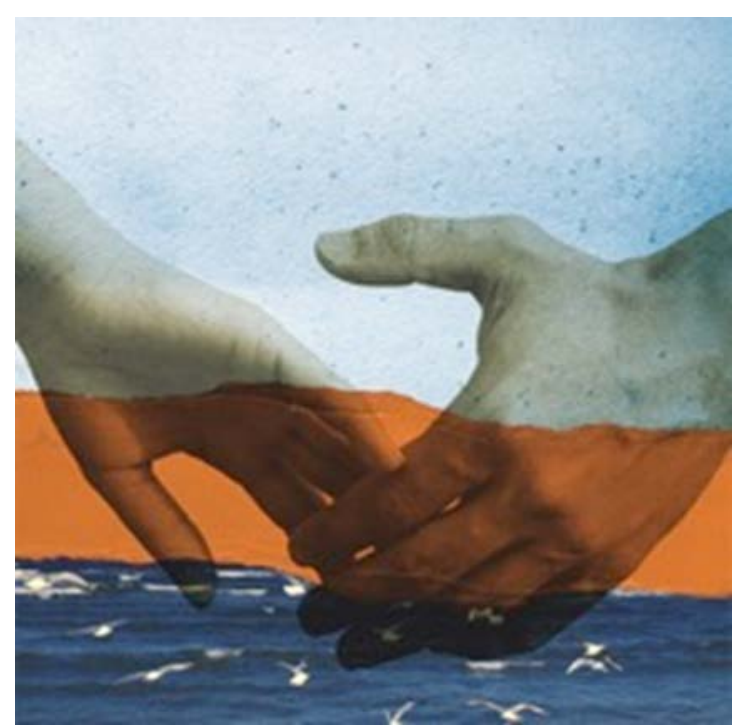

Figure 8. The "denouements" of the Legend "Death of the Sarnıç Kızlar"

The image of birds flying over the sea reflects the love of the couple, who died together, in a sad manner. With paper tissue forming the sky; the couple, who are blind is a witness to the love and death of the sky, and this causes the blue colour to lose its colour. "Denouements" is depicted by the ripped paper texture as it was in the previous stages of the myth however, it is preferred to use a transparent orange tone to describe a death embracing consent rather than a death in the context of 'murder'.

\section{CONCLUSION AND RECOMMENDATIONS}

\section{Conclusion}

In line with the scope of the work and with the goal of supporting the transfer of the intangible cultures to the tangible culture dimension, the digital collage method was used for illustration work for the first time. In line with the main aim of the work; the aim was to make the legends, which are cultural products regarding the teaching, facilitating to be remembered, shared better, artistic through the illustration. Legends; are referred to as ethnology 
products in the literature, while pointing to folk narratives in the form of short, straightforward people. As it is well known, the island of Cyprus is known as a very rich island in terms of its legends due to the cultural motives left by the many historical civilizations that it hosts.

As mentioned earlier, the Cypriot Legends, the transformation of the written expression of verbal expression which is the source of inspiration for the beginning of the work, in the name of the next step and contribution to cultural heritage; is based on techniques and / or features of surrealism (manipulation), cubism (collage), Dadaism (exaggeration), and pop art (bright color) art movements. Thus, in addition to these technical feature and / or features, the authors performed the illustration of legends with a "mixed" method by adding the ripped paper texture technique of its own signature.

The illustration works were designed by the "denouements" in 6 legends categorised as the legends on Mountain/Well/Plain and Legends on Sea/Lake/Shore in the Cypriot legends assessed by the digital collage method.

In this context, "denouements" can be categorized as 'turning into mountain / stone', 'end of life', 'disappearance / death'. In other words, the fact that the common "denouements" of the Cypriot legends is "death" is the fact that the ultimate end in the Cypriot community is only death related.

From this, we believe that it is possible for the Cypriot community to perceive that there is no perception of an "end" in circumstances other than death, the immutable truth of life, but perhaps the flow of events may come to another dimension. The fact that the end of everything is related only to "death" which is not in the hands of the human being, is not pessimistic about aspects of life; God is also referring to the strength of faith / fear as long as there is always a point of origin if there is no death.

In addition, blue and red colours were used predominantly in the studies. The blue colour, which is used as a symbol of male domination, determines the 'active' position of the man in selected myths in terms of 'passion of woman' and 'commodification of woman'. In the conclusions of the events, red colour was used because of the "denouements" such as 'turning into mountain / stone', 'end of living life', 'disappearance / death' with the wrath of God. It is also useful to say that the Cypriots have a "patriarchal" socio-cultural structure, based on the rhetoric of cultural product legends that are part of the past / history.

\section{Recommendations}

There are illustrations of critical points such as "Woman" / "Love", "Male / Love", "General Theme" and "Peak Point", unlike the "denouements" themes that are considered in addition to the current work done in the future work will allow the legends to enrich themselves in the artistic context. In addition, we believe that by increasing the quality and quantity of the representations to be studied, it will help to better understand the structure of Cypriot culture.

Other than that, analysis and visualization of legends or legends in all Cypriot legends categorized in other subheadings, not just the legends considered in the study, will enrich the cultural heritage.

As a result of the work done; we are convinced that all the myths will be useful in explaining patriarchal beliefs before they make a definite generalization of the legends that are observed to be stronger than the emphasis on the "deaths" and "denouements" of God's faith and fear. Except that; A study involving the discursive representation of man, the peaks and "denouements" of events will make it possible to have a general knowledge of the ancient Cypriot culture.

Moreover, the next step should be the assessment of text books or educational reference books in the South Cyprus, the categorisation and analysis of the legends in the Greek Cypriot literature in addition to the identification similarities as well as differences with the legends in the North Cyprus literature, which all have a crucial role in the reflection of cultural structure of both Turkish Cypriot and Greek Cypriot, that Cyprus as a whole island.

\section{DECLARATION}

We do not have any copyright infringement in the work done, but we declare that the created digital collage based images belong to the corresponding author. 


\section{REFERENCES}

Ahmad, Y. (2006). The scope and definitions of heritage: from tangible to intangible. International journal of heritage studies, 12(3), 292-300.

Akdoğan, B. (2001). Sanat, Sanatç1, Sanat Eseri \& Ahlak. Ankara University, Journal of Communication Faculty, 42, 213247.

Arslanoğlu, İ. (2000). Kültür \& Medeniyet Kavramları. Türk Kültürü E Hacı Bektaş Velî Araştırma Dergisi, (15).

Bahar, H. İ. (2009). Sosyoloji (3rd Ed.). Ankara: Usak Press.

Basat, E. M. (2013). Somut \& Somut Olmayan Kültürel Mirasi Birlikte Koruyabilmek. Millî Folklor, 61.

Bayat, F. (2016). Mitolojiye Giriş. İstanbul: Ötüken Neşriyat AŞ.

Bingöl, B. (2010). Sanat özgürlüğü. Hacettepe University, Faculty of Law Journal, 1(2) 92-139. Retrieved from http://www.hukukdergi.hacettepe.edu.tr/dergi/2_makale_05.pdf

Binyazar, A. (2010). Toplum E Edebiyat. İstanbul: Can Press.

Bülbül, M., Türkoğlu, S., \& Küzeci, D. (2014). Edebiyat \& Toplumsal İşlevi. Atatürk Üniversitesi Kazım Karabekir Ĕ̆itim Fakültesi Dergisi, (29). Çeçen, A. (1984). Kültür \& Politika. Hil Press.

Çekül Vakfı. (2013). Retrieved from http://www.cekulvakfi.org.tr/proje/cekulun-kulturel-miras-anlayış1

Dachy, M. (2006). Dada - The Revolt of Art. London: Thames and Hudson

Edward, L. S. (2004). 20. Yüzyılda Görsel Sanatlar. Trans. Ebru Kılıç, Begüm Kovulmaz, Osman Akınhay, (Visual Arts in the 20th Century, pub. In 1996), Istanbul: Akbank Press.

Elbir, B. (2006). Edebiyat Bilgi \& Kuramlari. Ankara: Pegem Press.

Etimoloji Türkçe (on-line). Türkçe Etimiloji Sözlüğü. Retrieved on 16 January 2017 from http://www.etimolojiturkce.com/kelime/efsane

Fatih, A. M. A. N. (2012). Bronislaw Malinowski'nin Kültür Teorisi. Review of the Faculty of Theology of Uludag University, 21(1).

Gökçeoğlu, M. (2004). Kıbrıs Türk Halkbilimi Sözel Kültür Değerlerimiz: Efsanelerimiz. Nicosia: Gökçeoğlu Press.

Gümüştekin, N. (n.d). “Kültür” Kavrami \& Osmanli' dan Günümüze Kültürel Yapinin İncelenmesi. Retrieved from http://www.ayk.gov.tr/wp-content/uploads/2015/01/G\%C3\%9CM\%C3\%9C\%C5\%9ETEKIN-Nuray-

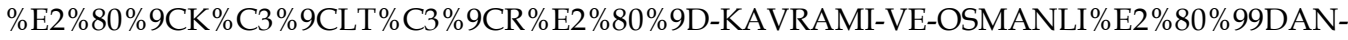
G\%C3\%9CN\%C3\%9CM\%C3\%9CZE-K\%C3\%9CLT\%C3\%9CREL-YAPININ$\%$ C4\%BONCELENMES\%C4\%B0.pdf

Hofmann, I. E. (1996). Documents of Dada and Surrealism: Dada and Surrealist journals in the Mary Reynolds collection. Art Institute of Chicago Museum Studies, 131-197.

Houser, A. (1958). The Social History of Art: Rococo. Classicism, Romanticism. Vintage Books.

İslimyeli, N. (1973). Sanat terimleri ansiklopedisi. Ankara: Sanat Press.

ISMEP. (2014). İSMEP Rehber Kitaplar: Kültürel Mirasın Korunması. Retrieved on 24 April from http://www.guvenliyasam.org/wp-content/uploads/2016/02/KULTUREL.pdf

Kaplan, R. K., İleri, C., \& Öztürk, A. (1998) Edebiyat Bilgi \& Kuramları. Eskişehir: T.C. Anadolu Üniversitesi Press.

Kösemihal, N. Ş. (1964). Edebiyat Sosyolojisine Giriş. Sosyoloji Dergisi, 2(19-20), 1-37.

McNeese, T., \& Picasso, P. (2006). Pablo Picasso. New York: Chelsea House Publishers.

Nesim, A., \& Oznur, S. (2011). Kıbrıs Türk Kültürü \& Kıbrıs Efsaneleri. Lefkosa: Gokada Press.

Oskay, A. (2003). Kubist kolajlar. Journal of Istanbul Kultur University, 3, 51-56.

Özdemir, E. (1994). Türk \& Dünya Edebiyatı. Ankara: Kültür Bakanlığı Yay.

Rojewski, J. W. (2005). A typical American family? How adoptive families acknowledge and incorporate Chinese cultural heritage in their lives. Child and Adolescent Social Work Journal, 22(2), 133-164.

Roth, K. (1998). Crossing boundaries: the translation and cultural adaptation of folk narratives. Fabula, 39(3/4), 243.

Sözen, M., \& Tanyeli, U. (1986). Sanat kavram \& terimleri sözlüğü. Istanbul: Remzi.

TDK (1992). Türkçe Sözlük. İstanbul: Milliyet.

Türkkahraman, M. (2012). The role of education in the societal development. Journal of Educational and Instructional Studies in the World, 2(4). 
Ulker, R. (2012). Turkish Children's Drawing of Nature in a Certain Way: Range of Mountains in the Back, the Sun, Couple of Clouds, a River Rising from the Mountains. Educational Sciences: Theory and Practice, 12(4), 3173 3180

Ünver, E. (2016), Sanat ve Toplum, Bilim - Teknoloji Dergisi.

Vangölü, Y. B. (2016). Geçmişten Günümüze Gerçeküstücülük/Surrealism: Past and Present. Atatürk Üniversitesi Sosyal Bilimler Enstitüsü Dergisi, 20(3).

Yilmaz, F., \& Kahraman, A. D. (2015). Science and Nature Perception in the Images and Pictures of the Children. Procedia-Social and Behavioral Sciences, 176, 650-658.

\section{http://www.ejmste.com}

